\title{
UJI AKTIVITAS NEPHROROTEKTIF EKSTRAK AIR DAUN AFRIKA (Vernonia amygdalina ) PADA TIKUS MODEL GAGAL GINJAL
}

\author{
*Budi Siswanto, *Ranti Dwi Astriani, *Reza.TP.
}

\begin{abstract}
Abstraks
Latar Belakang.Penyakit Gagal Ginjal adalah suatu penyakit dimana fungsi organ ginjal mengalami penurunan hingga akhirnya tidak lagi mampu bekerja sama sekali dalam hal penyaringan pembuangan elektrolit tubuh, menjaga keseimbangan cairan dan zat kimia tubuh seperti sodium dan kalium didalam darah atau produksi urine.Pemanfaatan bahan-bahan alam berupa herbal di Indonesia mulai dikembangkan, hal terjadi karena masyarakat menyadari dampak efek samping yang ditimbulkan dari obat-obat sintetik lebih besar dibandingkan dengan obat-obat yang terbuat dari herbal. Rumusan Masalah ekstrak daun afrika (vernonia amygdalina) dapat melindungi kerusakan ginjal pada tikus putih yang di induksi dengan gentamisin. Tujuan mengetahui bukti ilmiah kemampuan ekstrak daun afrika ((vernonia amygdalina) dalam melindungi kerusakan ginjal tikus putih akibat perlakuan nephrotoksik gentamisin.Hipotesa Ada pengaruh Ektraks Air Daun Afrika ((vernonia amygdalina) terhadap perlindungan Ginjal.Disain Penelitian ini bersifat eksperimen murni secara deskriptif yang menganalisa perubahan creatinin dan BUN. Kesimpulan ada pengaruh pemberian ekstrak daun afrika(Vernonia amygdalina), terhadap kadar ureum dan kreatinin tikus putih (Rattus Novergicus) jantan galur Wistar yang di induksi gentamisin dan kaptoptil yang bermakna secara statistik, yaitu Pada perlakuan 1 bahwa Kadar Ureum $44.7 \pm 11.12 \mathrm{mg} / \mathrm{dl}$, dan kreatinin serum darah $0.7 \pm 0.06 \mathrm{mg} / \mathrm{dl}$. Pada perlakuan 2 kadar ureum serum darah adalah $37.1 \mathrm{mg} / \mathrm{dl} \pm 6.34 \mathrm{mg} / \mathrm{dl}$ dan kadar kreatinin serum darah $0.6 \pm 0.13 \mathrm{mg} / \mathrm{dl}$. Pada perlakuan 3 kadar ureum serum darah $29.4 \pm 7.61 \mathrm{mg} / \mathrm{dl}$ dan kreatinin serum $0.5 \pm 0.16 \mathrm{mg} / \mathrm{dl}$. Perlakuan 3 memberikan pengaruh yang cukup besar bila dibandingkan dengan perlakuan 1, perlakuan 2 dan kontrol $(+)$ yaitu sebesar $29.4 \pm 7.61 \mathrm{mg} / \mathrm{dl}$ pada kadar serum ureum dan $0.5 \pm 0.16$ $\mathrm{mg} / \mathrm{dl}$ pada kreatinin serum darah.
\end{abstract}

Kata Kunci : Daun Afrika, Creatinin, BUN, Gentamisin

*Poltekkes Kemenkes Banten 


\section{Pendahuluan}

Indonesia merupakan negara yang beriklim tropis sehingga sehingga mempunyai hayati yang berlimpah. Salah satu kekayaannya adalah vegetasi tumbuh-tumbuhan yang melimpah dan dapat dimanfaatkan oleh masyarakat baik sebagai bahan makanan atau digunakan sebagai obat tradisional untuk mengatasi berbagai macam gangguan kesehatan (Hariana, Arief, 2003)

Pemanfaatan bahan-bahan alam berupa herbal di Indonesia mulai dikembangkan, hal terjadi karena masyarakat menyadari dampak efek samping yang ditimbulkan dari obatobat sintetik lebih besar dibandingkan dengan obat-obat yang terbuat dari herbal, selain itu harganya murah, mudah terjangkau, mudah dibuat dan mudah juga diperolehnya (Wijayakusuma, dkk, 1996).

Salah satu tanaman herbal yang digunakan masyarakat antara lain daun afrika (Vernonia Amygdalina ), penelitian daun afrika belum begitu intensif dilakukan secara ilmiah, namun secara testimoni dari masyarakat dan dari beberapa literatur diungkapkan bahwa daun afrika sangat baik digunakan sebagai antidiabetes, hipertensi, reumatik, pengapuran tulang, penyakit ginjal dan lain-lainya, selain itu dapat digunakan sebagi obat luar seperti radang kulit, luka, dan infeksi.

Beberapa penelitian tentang penggunaan daun afrika (Vernonia Amygdalina ) sebagai herbal seperti ; Ojiako dan Nwanjo (2006) hepatotoksik atau hepatoprotektif, Abosi AO, Raseroka BH (2003) antimalaria, Atangwho dkk (2007) fungsi ginjal pada tikus diabetik.

Menurut Ijeh, I.I., dan Ejike, E.C. (2011), dari hasil penelitian mengatakan bahwa tanaman daun Afrika banyak mengandung nutrisi dan senyawa kimia, antara lain adalah sebagai berikut: protein $19,2 \%$, serat $19,2 \%$, karbohidrat $68,4 \%$, lemak 4,7\%, asam askorbat 166,5 mg/100 g, karotenoid 30 mg/100 g, kalsium 0,97 g/ $100 \mathrm{~g}$, besi 7,5 $\mathrm{mg} / 100 \mathrm{~g}$, fosfor, kalium, sulfur, natrium, mangan, tembaga, zink, magnesium dan selenium. Senyawa kimia yang terkandung dalam daun Afrika antara lain ; golongan saponin 
(vernoniosida dan steroid saponin), seskuiterpen lakton (vernolida, vernodalol, vernolepin, vernodalin, dan vernomygdin), flavonoid, koumarin, asam fenolat, lignan, xanton, terpen, dan glikosida steroid seperti vernonioside B1 dan vernoniol B1 (Yeap, et all, 2010)

Penyakit Gagal Ginjal adalah suatu penyakit dimana fungsi organ ginjal mengalami penurunan hingga akhirnya tidak lagi mampu bekerja sama sekali dalam hal penyaringan pembuangan elektrolit tubuh, menjaga keseimbangan cairan dan zat kimia tubuh seperti sodium dan kalium didalam darah atau produksi urine. Penyakit gagal ginjal ini dapat menyerang siapa saja yang menderita penyakit serius atau terluka dimana hal itu berdampak langsung pada ginjal itu sendiri, yang lebih sering terjadi pada orang yang berusia dewasa, terlebih pada kaum lanjut usia.( Price, sylvia, 1994)

Menurut Santoso Djoko ( 2008), di Indonesia penderita penyakit gagal ginjal mencapai angka 20\%. Pusat data dan informasi Perhimpunan Rumah Sakit Seluruh Indonesia (PDPERSI) menyatakan jumlah penderita gagal ginjal kronik diperkirakan sekitar 50 orang per satu juta penduduk. Rianita Juniati (2015) dalam seminarnya mengatakan dari jumlah penduduk Indonesia kurang lebih 250 juta, prevalensi gagal ginjal diperkirakan 400 ribu, diperkirakan angka insiden penyakit gagal ginjal dari 100 juta penduduk terdapat 100 ribu pasien gagal gibjal dan 25 ribu pasien baru tiap tahunnya.

Berdasarkan hal tersebut, maka peneliti tertarik untuk menguji aktivitas nephroprotektif ekstrak daun afrika (vernonia amygdalina). Pada percobaan ini peneliti menggunakan tikus putuh jenis Rattus novergicus yang di induksi dengan gentamisin dan kaptopril , sehingga peneliti dapat melihat indikator kerusakan ginjal melalui serum darah tikus.

\section{Metodologi Penelitian}

Rancangan penelitian yang digunakan dalam penelitian ini adalah bersifat eksperimen murni secara deskriptif yang menganalisa perubahan kadar ureum serum darah dan kadar kreatinin serum darah tikus putih galur wistar 
jenis Rattus Novergicus, yang dilakukan selama 14 hari di laboratorium Analis Kesehatan Tangerang. Populasi dalam penelitian ini adalah tikus putih jenis Rattus Novergicus dewasa dengan berat badan 200 - 300 gr yang diperoleh dari fakultas kedokteran hewan IPB Bogor. Sampel yang digunakan dalam penelitian ini sebanyak 30 ekor tikus dengan 4 perlakuan

\section{Hasil}

Setelah 3 hari dilkukan induksi dengan gentamisin dan kaptopril terjadi peningkatan kadar ureum darah yang menunjukkan adanya pengaruh dari induksi, setelah induksi dihentikan terjadi perbaikan fungsi ginjal yang terlihat dari penurunan kadar ureum dan kreatinin pada kelompok perlakuan (P) karena adanya homeostasis, tetapi setelah itu kadar ureum dan kreatinin stabil sampai hari ke 14. Penurunan kadar ureum dan kreatinin lebih besar pada kelompok yang diberi ekstrak daun afrika (Vernonia amygdalina) pada semua dosis dibandingkan dengan kelompok kontrol negatif, hal ini menunjukkan adanya efek perbaikan ginjal, data hasil penelitian dapat dilihat pada tabel 1 dan gambar 1 dibawah ini,

Tabel 1. Hasil analis Univariat kadar ureum

\begin{tabular}{|c|c|c|c|c|r|}
\hline $\begin{array}{c}\text { Tikus } \\
\text { Percobaan }\end{array}$ & K (+) & K (-) & P1 & P2 & \multicolumn{1}{|c|}{ P3 } \\
\hline 1 & 20 & 39.5 & 37.5 & 38.3 & 19.6 \\
\hline 2 & 23 & 78.8 & 62.8 & 28.6 & 26.1 \\
\hline 3 & 19 & 92.1 & 36.8 & 44 & 25.2 \\
\hline 4 & 17 & 73.0 & 43.6 & 29.9 & 28.7 \\
\hline 5 & 24 & 67.4 & 52.9 & 40.3 & 39.5 \\
\hline 6 & 27 & 69.5 & 34.3 & 41.3 & 37.3 \\
\hline Rata \pm SD & $\mathbf{2 1 . 7} \pm \mathbf{3 . 6 7}$ & $\mathbf{7 0 . 1} \pm \mathbf{1 7 . 3 9}$ & $\mathbf{4 4 . 7} \pm \mathbf{1 1 . 1 2}$ & $\mathbf{3 7 . 1} \pm \mathbf{6 . 3 4}$ & $\mathbf{2 9 . 4 \pm 7 . 6 1}$ \\
\hline
\end{tabular}

Keterangan

Kelompok K (+) : Diberi pakan normal

Kelompok K (-) : Di induksi gentamisin dan kaptopril

Kelompok P1 : Ekstrak Daun Afrika $50 \mathrm{mg} / \mathrm{Kg} \mathrm{BB}$

Kelompok P2 : Ekstrak Daun Afrika $100 \mathrm{mg} / \mathrm{Kg} \mathrm{BB}$

Kelompok P3 : Ekstrak Daun Afrika 200 mg/Kg BB 


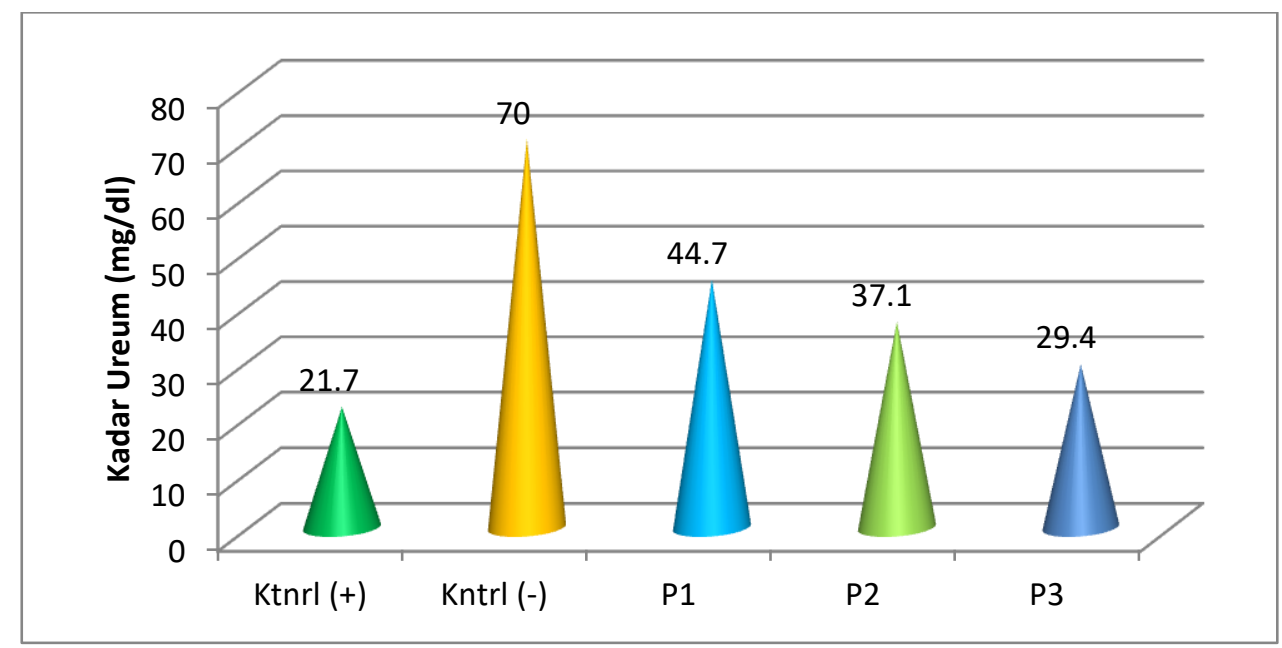

Gambar 1. Kurva kadar ureum serum darah

Hasil penelitian menunjukkan rata-rata kadar ureum pada kelompok yang diberi sedian uji menunjukkan penurunan kadar ureum darah setelah sebelas hari (hari ke 14) dan secara statistik menunjukan hasil yang bermakna $(p) \leq 0.05$. Seperti yang terlihat pada Tabel 1 dan gambar 1, dengan rata - kadar ureu serum darah sebagai berikut ; pada kontrol positif (+) adalah $21.7 \pm 3.67$, kontrol negatif (-) adalah $70.1 \pm 17.39$, sedangkan rata-rata kadar ureum pada sedian uji perlakuan 1 (50 mg/Kg BB) sebesar $44.7 \pm 11.12$, perlakuan $2(100 \mathrm{mg} / \mathrm{Kg}$ BB) sebesar $37.1 \pm 6.34$, dan pada perlakuan 3 (200 mg/Kg BB) sebesar $29.4 \pm 7.6$

Tabel 2. Hasil analis Univariat kadar Kreatinin

\begin{tabular}{|c|c|c|c|c|r|}
\hline $\begin{array}{c}\text { Tikus } \\
\text { Percobaan }\end{array}$ & K (+) & K (-) & P1 & P2 & \multicolumn{1}{|c|}{ P3 } \\
\hline 1 & 0.73 & 0.8 & 0.79 & 0.54 & 0.55 \\
\hline 2 & 0.64 & 1.0 & 0.78 & 0.63 & 0.52 \\
\hline 3 & 0.47 & 1.3 & 0.78 & 0.79 & 0.65 \\
\hline 4 & 0.39 & 1.0 & 0.67 & 0.47 & 0.18 \\
\hline 5 & 0.76 & 1.4 & 0.76 & 0.77 & 0.52 \\
\hline 6 & 0.67 & 1.6 & 0.65 & 0.69 & 0.52 \\
\hline Rata-rata \pm sd & $\mathbf{0 . 6} \pm \mathbf{0 . 1 5}$ & $\mathbf{1 . 2 \pm 0 , 3 1}$ & $\mathbf{0 . 7} \pm \mathbf{0 . 0 6}$ & $\mathbf{0 . 6} \pm \mathbf{0 . 1 3}$ & $\mathbf{0 . 5} \pm \mathbf{0 . 1 6}$ \\
\hline
\end{tabular}




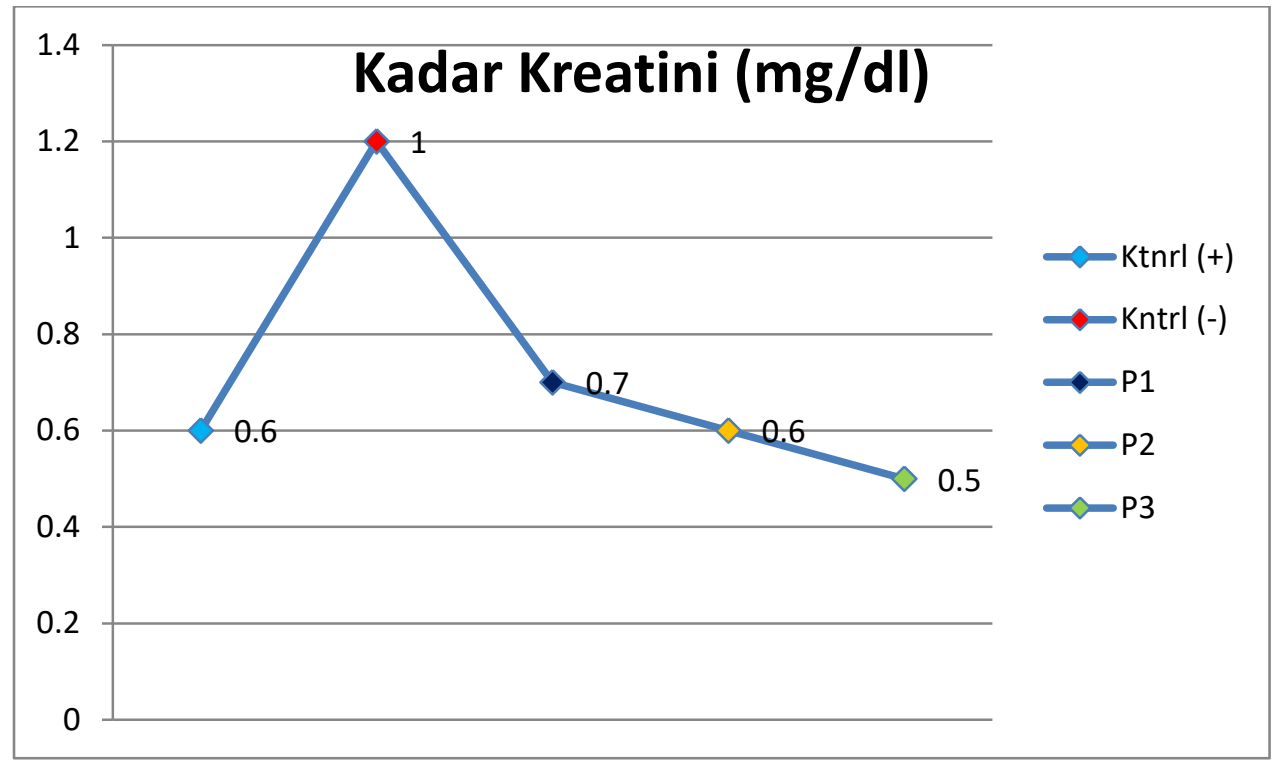

Gambar 2 : Kurva kadar kreatinin serum darah

Pada tabel 2 dan gambar 2 diperoleh nilai $(p)$ untuk semua menunjukkan data hasil rata-rata kadar kelompok perlakuan adalah $>0.05$ kreatinin serum darah pada kelompok sehingga dapat dikatakan semua data kontrol positif $(+)$ adalah $0.6 \pm 0.15$, pada kontrol negatif (-) adalah $1.2 \pm$ 0.31, sedangkan rata-rata kadar kreatinin pada sedian uji $(50 \mathrm{mg} / \mathrm{Kg}$ BB) perlakuan 1 sebesar $0.7 \pm 0.06$, pada sedian uji $(100 \mathrm{mg} / \mathrm{Kg} \mathrm{BB})$ perlakuan 2 adalah $0.6 \pm 0.13$, dan pada sedian uji (200 mg/Kg BB) perlakuan 3 adaalah menunjukkan hasil sebesar $0.5 \pm 0.16$

Dari hasil uji normalitas terhadap kadar ureum dan kreatinin terdistribusi normal, kemudian dilakukan dengan uji hogenitas, dari hasil uji homogenitas ini didapatkan nilai $p \geq 0.05$ yang artinya varians data homogen sehingga dapat dilakukan uji one - way Anova. Hasi uji ANOVA menunjukkan nilai $\mathrm{p} \leq 0,05$ yang artinya paling tidak terdapat perbedaan kadar ureum dan kreatinin yang bermakna pada dua kelompok sehingga dapat dilanjutkan dengan uji Post Hoc. 
Tabel 3. Hasil analis uji pos hoc kadar ureum dan Kreatinin

\begin{tabular}{|c|c|c|c|}
\hline Dependent Variable & (I) KELOMPOK & (J) KELOMPOK & Sig. \\
\hline \multirow{20}{*}{ UREUM } & \multirow{4}{*}{1.00} & 2.00 & .000 \\
\hline & & 3.00 & .001 \\
\hline & & 4.00 & .016 \\
\hline & & 5.00 & .208 \\
\hline & \multirow{4}{*}{2.00} & 1.00 & .000 \\
\hline & & 3.00 & .000 \\
\hline & & 4.00 & .000 \\
\hline & & 5.00 & .000 \\
\hline & \multirow{4}{*}{3.00} & 1.00 & .001 \\
\hline & & 2.00 & .000 \\
\hline & & 4.00 & .217 \\
\hline & & 5.00 & .017 \\
\hline & \multirow{4}{*}{4.00} & 1.00 & .016 \\
\hline & & 2.00 & .000 \\
\hline & & 3.00 & .217 \\
\hline & & 5.00 & .212 \\
\hline & \multirow{4}{*}{5.00} & 1.00 & .208 \\
\hline & & 2.00 & .000 \\
\hline & & 3.00 & .017 \\
\hline & & 4.00 & .212 \\
\hline \multirow{20}{*}{ KREATININ } & \multirow{4}{*}{1.00} & 2.00 & .000 \\
\hline & & 3.00 & .221 \\
\hline & & 4.00 & .711 \\
\hline & & 5.00 & .252 \\
\hline & \multirow{4}{*}{2.00} & 1.00 & .000 \\
\hline & & 3.00 & .000 \\
\hline & & 4.00 & .000 \\
\hline & & 5.00 & .000 \\
\hline & \multirow{4}{*}{3.00} & 1.00 & .221 \\
\hline & & 2.00 & .000 \\
\hline & & 4.00 & .387 \\
\hline & & 5.00 & .023 \\
\hline & \multirow{4}{*}{4.00} & 1.00 & .711 \\
\hline & & 2.00 & .000 \\
\hline & & 3.00 & .387 \\
\hline & & 5.00 & .134 \\
\hline & \multirow{4}{*}{5.00} & 1.00 & .252 \\
\hline & & 2.00 & .000 \\
\hline & & 3.00 & .023 \\
\hline & & 4.00 & .134 \\
\hline
\end{tabular}




\section{Pembahasan}

Kadar ureum normal untuk tikus 5.0 - $29.0 \mathrm{mg} / \mathrm{dl}$, sedangkan kadar normal kreatinin untuk tikus adalah $0.81 \mathrm{mg} / \mathrm{dl}$ (Diah, 2003) dari data hasil penelitian pada tabel 1 , terlihat bahwa rata-rata kadar ureum pada kelompok kontrol Positif (+) adalah $21.7 \pm 3.67 \mathrm{mg} / \mathrm{dl}$ masih berada pada rentang normal, hal ini dikarenakan pada kelompok kontrol positif (+) tidak diperlakukan apapun, hanya diberikan makan minum standar. Kadar ureum dalam serum darah tikus dapat dipengaruhi oleh beberapa faktor antara kain faktor patologis seperti terjadinya kerusakan ginjal baik akut maupun kronis dan faktor perlakuan pada hewan seperti pemberian pakan. Menurut Meyer, 2004, kenaikan kadar ureum darah dianggap sebagai tanda adanya kerusakan ginjal hanya apabila disertai dengan pemeriksaan urine (urinalisis) dan disertai dengan yandatanda klinis yang mendukung untuk menentukan diagnosa gagal ginjal.

$$
\begin{aligned}
& \text { Sedangkan rata-rata kadar } \\
& \text { kreatinin pada kelompok kontrol } \\
& \text { Positif (+) adalah } 0.6 \pm 0.15 \mathrm{mg} / \mathrm{dl}
\end{aligned}
$$

masih menunjukkan bahwa rata-rata kadar kreatinin pada kelompok ini masih berada dalam rentang normal, hal ini karena pada kelompok kontrol positif (+) tidak diberikan perlakuan apapun, kecuali pakan standar secara ad libitum. Menurut Sumarny. 2006. Kadar kreatinin serum darah relatif tidak dipengaruhi oleh makanan, umur, jenis kelamin, aktivitas dan diet. Kreatinin seluruhnya diekresikan ke dalam urin melalui filtrasi ginjal melalui filtrasi glomerulus, sehingga apabila terjadi kerusakan ginjal maka kreatinin akan terakumulasi dalam darah, dan dapat dijadikan untuk mendiagnosis adanya gangguan ginjal dengan mengukur laju filtrasi glomerulus.

Pemberian Gentamisin dan kaptopril pada tikus percobaan akan terakumulasi pada korteks ginjal, yang akan menyebabkan kerusakan sel ginjal sehingga mengakibatkan stress oksidatif yang memicu pelepasan lisosom yang akan merusak sekitarnya sehingga mengakibatkan terjadinya gangguan ekresi ureum dan Kreatinin. (Larasari, 2009). Blood Urea 
Nitrogen (BUN) dan kreatinin merupakan zat sisa pembuangan dari metabolisme normal yang diekresikan melalui urin, sehingga pada keadaan normal kadarnya rendah di dalam darah. Tetapi bila terjadi gangguan fungsi ginjal maka jumlah BUN dan kreatinin yang diekresikan oleh ginjal menurun sehingga akan terjadi akumulasi kadar senyawa - senyawa tersebut, sehingga akan meningkat kadarnya di dalam darah. Oleh karena itu kadar BUN dan Kreatinin di dalam darah dapat dijadikan paramater gangguan fungsi ginjal.

Pada kelompok kontrol negatif () rata-rata kadar ureum serum darahnya $70.1 \pm 17.39 \mathrm{mg} / \mathrm{dl}, \quad$ dan rata-rata kadar kreatinin serum darahnya adalah $1.2 \pm 0.31 \mathrm{mg} / \mathrm{dl}$, pada kelompok ini menunjukkan hasil yang lebih tinggi bila dibandingkan dengan kelompok positif (+) dan menunjukkan hasil lebih dari kadar rata-rata normal, hal ini bisa terjadi karena kelompok kontrol negatif (-) ini hanya diberikan induksi gentamisin dan kaptopril selama tiga hari sehingga terjadi penumpukan induksi dengan gentamisin dan kaptopril pada bagian kortek ginjal yang dapat merusak organ ginjal dan menimbulkan tubulointerstitial nefritis akut sehingga menimbulkan gangguan pengeluaran oleh saluran tubulus dan terjadi akumulasi dalam saluran yang mengakibatkan meningkatnya kadar ureum dan kreatinin serum dalam pembuluh darah.

Meyer, (2004), menyebutkan bahwa Salah satu penyebab terjadinya peningkatan kadar ureum dan kreatinin adalah adanya radikal bebas yang berlebihan sehingga menyebabkan terjadinya stres oksidatif yang berdampak kepada kerusakan sel ginjal. Radikal bebas pada tikus penelitian ini merupakan mekanisme nefrotoksik dari gentamisin dan kaptopril, dan antioksidan dari daun afrika (Vernonia amygdalina ), antioksidan ini dapat melindungi dari nefrotoksik akibat radikal bebas dan reactive oxygen species (ROS) yang menginduksi stres oksidatif dalam ginjal. Peningkatan radikal bebas dan ROS akan menyebabkan terjadinya kerusakan sel dimana bagian-bagian sel akan keluar dan berikatan dengan 
protein fibronektin di dalam lumen tubulus ginjal, keadaan ini akan menyebabkan penyumbatan lumen sehingga kadar ureum dan kreatinin tidak dapat dikeluarkan dengan baik

Muhyi dkk, 2010 dalam penelitiannya mengatakan bahwa pemberian ekstrak kulit manggis dapat menurunkan peningkatan kadar ureum dan kreatinin serum tikus putih jantan yan di induksi isoniazid. Data rata-rata kadar ureum dan kreatinin serum pada kelompok perlakuan yang di induksi gentamisin dan kaptopril dan diberikan ekstrak daun afrika (Vernonia amygdalina seperti yang terlihat pada tabel 1 dan tabel 2

Penurunan kadar rata-rata ureum dan kreatinin pada perlakuan 1, 2 dan 3 dikarenakan terdapatnya senyawa golongan saponin, flavonoid dan xanton yang terkandung dalam daun afrika (Vernonia amygdalina ). Menurut Karim dkk, (2009) Senyawasenyawa ini dapat menghambat terjadinya lipid peroksida dengan cara mencegah radikal bebas dan meningkatkan konsentrasi antioksidan intraseluler dari analisis hasil data penelitian ini, didadaptkan rata-rata kadar ureum serum darah pada kelompok perlakuan 1 sebesar $44.7 \pm$ 11.12 (mg/dl) dan kadar kreatinin serum darahnya sebesar sebesar $0.7 \pm$ 0.06 (mg/dl), dan perlakuan 2 kadar rata -rata serum darahnya sebesar 37.1 $\pm 6.34(\mathrm{mg} / \mathrm{dl})$, kadar rata-rata kreatinin serum darahnya $0.6 \pm 0.13$ $(\mathrm{mg} / \mathrm{dl})$, sedangkan pada perlakuan 3 kadar rata -rata serum darah sebesar $29.4 \pm 7.61(\mathrm{mg} / \mathrm{dl})$ dan kadar rata-rata kreatinin serum darahnya sebesar 0.5 $\pm 0.16(\mathrm{mg} / \mathrm{dl})$

Dari hasil penelitian menunjukkan bahwa ekstrak daun afrika (Vernonia amygdalina) mampu menurunkan kadar ureum dan kreatinin serum darah, kelompok perlakuak 3 memberikan hasil hasil pengaruh paling besar untuk kadar ureum serum darah sebesar 29.4 \pm 7.61 (mg/dl) dan kreatinin serum darah sebesar $0.5 \pm 0.16 \quad(\mathrm{mg} / \mathrm{dl})$, mendekati kelompok kontrol positif (+) kadar ureum serum sebesar $21.7 \pm$ $3.67(\mathrm{mg} / \mathrm{dl})$, dan kadar kreatinin serum darah sebesar $0.6 \pm 0.15(\mathrm{mg} / \mathrm{dl})$ 


\section{Kesimpulan}

Ada pengaruh pemberian ekstrak daun afrika(Vernonia amygdalina), terhadap kadar ureum dan kreatinin seum darah tikus putih (Rattus Novergicus) jantan galur wistar yang di induksi gentamisin dan kaptoptil yang secara statistik menghasilkan hasil yang bermakna.

Berdasarkan pemberian uji ekstrak daun Afrika ((Vernonia amygdalina ) hasil uji menunjukkan bahawa pemberian ekstrak pada kelompok perlakuan 3 memberikan pengaruh cukup besar yaitu untuk kadar rata -rata serum darah sebesar $29.4 \pm 7.61(\mathrm{mg} / \mathrm{dl})$ dan kadar rata-rata kreatinin serum darahnya sebesar 0.5 $\pm 0.16(\mathrm{mg} / \mathrm{dl})$, sedangkan yang kedua memberikan pengaruh cukup besar yaitu perlakuan 2 dengan kadar rata rata serum darah sebesar $37.1 \pm 6.34$ $(\mathrm{mg} / \mathrm{dl})$ dan kadar rata-rata kreatinin serum darah $0.6 \pm 0.13(\mathrm{mg} / \mathrm{dl})$, dan ketiga adalah kelompok perlakuan 1 dengan menunjukkan hasil sebesar 1 sebesar $44.7 \pm 11.12(\mathrm{mg} / \mathrm{dl})$ dan kadar kreatinin serum darahnya sebesar sebesar $0.7 \pm 0.06(\mathrm{mg} / \mathrm{dl})$.

\section{Daftar Pustaka}

Abosi AO, Raseroka BH (2003) In vivo antimalarial activity of Vernonia amygdalina. Br. J. Biomedical Sci. 60(2): 89-91

Agbogidi, O. M., \& Akpomorine, M. O. (2013). Health And Nutritional Benefits of Bitterleaf (Vernonia Amygdalina Del.). Hetero Group of Journal

Arief, H, 2003. Tumbuhan Obat dan Khasiatnya 2. PT. Niaga Swadaya. Jakarta

Atangwho, I. J., Ebong, P. E., Eteng, M. U., Eyong, E. U. \& Obi, A. U. (2007), "Effect of Vernonia amygdalina Del. Leaf on Kidney function of diabetic rats. International Journal of Pharmacology 3, 143-148.

Choi YJ, Chakraborty S, Nguyen V, Nguyen C, Kim BK, Shim SI, Suki WN, Truong LD.

Peritubular capillary loss is associated with chronic tubulointerstitial injury in human kidney: altered expression of vascular endothelial growth factor. Hum Pathol 2000;31:1491-7.

Depkes RI. (1995). Materia Medika Indonesia. Jilid VI. Jakarta: Depkes RI. Hal. 297-303, 321325, 333-337.

Diah, 2003 .Bersahabat dengan hewan coba, FKH Universitas 
Airlangga, Gajah Mada

University Press,

YogyakartaMeyer DJ,Harvey

JW 2004 .Veterinary

Laboratory Medicine :

Interpretation and Diagnosis,

Philadelphia : Saunders.

Ditjen POM. (2000). Parameter

Standar Umum Ekstrak

Tumbuhan Obat. Jakarta:

Departemen Kesehatan RI. Hal. 1, 10-11.

Ejoh, R. A., Nkonga, D. V., Innocent, $\mathrm{G} \&$ Moses, M. C. (2007), "Nutritional composition of some nonconventional leafy vegetables consumed in Cameroun", Pakistan Journal of Nutrition $6,712-714$

Forimbi, E. O., Owoeye, O. (2011). Antioxidative and chemopreventive properties of Vernonia amygdalina and Garcinia biflavonoid. international Journal of Environmental Research and Public Health.

Ghosh D, Konishi T. 2007.

Anthocyanins and anthocyaninrich extracts: role in diabetes and eye function. Asia Pac J Clin Nutr 16(2) : $\quad$ 200-208.

Ibrahim, G., Abdurahman, E.M., dan Katayal, U.A. (2004). Pharmacognostic Studies On The Leaves Of Vernonia amygdalina Del. (Asteraceae).
Nig. J. Nat. Orid. And Med. 08

(1): 8-10.

Ijeh, I. I. \& Ukweni, A. I. (2007), "Acute effect of administration of ethanol extracts of Ficus exasperata vahl on kidney function in albino rats ," Journal of Medicinal Plants Research 1(2), 2729

Ijeh, I.I., dan Ejike, E.C. (2011). Current Perspectives on the Medical Potentials of Vernonia amygdalina Del. Journal of Medical Plants Research. 57: 1051- 1061

Ijeh, I.I., dan Ejike, E.C. (2011). Current Perspectives on the Medicaln Potentials of Vernonia amygdalina Del. Journal of Medical Plants Research. 57: 1051-1061.

Iwakolun, B.A., Efedede, B.U., Alabi, S.J.A., Oduala, T., Magbagbeola, O.A., dan Akinwande, A.I. (2006). Hepatoprotective and Antioxidant Activities of Vernonia amygdalina on Acetaminophen-Induced Hepatic Damage in Mice. Journal of Medicinal Food. (4) : 524-530.

Karimi G, Khoei A, Omidi A, Kalantari M, Bababei J, Elahe T, Razavi BM. 2010. Protective effect of aqueous and ethanolic extracts of Portulaca oleracea againts cisplatin induced 
nephrotoxicity. Iran. Basic

Medical Sciences. 13: 31-5.

Kataya H A H, Hamza A E A. 2008.

Red Cabbage (Brassica

oleracea) Ameliorates Diabetec

Nephropathy in Rats.

Complement Alternat Med

$5(3)$ : 281-287.

Larasari, L, Uji Efek Anthiperglikemia Ekstrak etanol Daun Binahong dengan Uji Toleransi Glukosa dan Uji diabetes Aloksan pada mencit jantan swiss Webster, Skripsi S-1, Universitas Garut, 2009;37-41

Lorz, C., Justo, P., Sanz, A.B., Egido, J., dan Ortiz, A. (2005). Role of Bcl-xL in Paracetamol-Induced Tubular Epithelial Cell Death. Kidney Int. 67: 14-18.

Maxwell P. HIF-1: an oxygen response syste with special relevance to the kidney. J Am Soc Nephrol 2003;14: 2712-22.

Meyer DJ,Harvey JW 2004

.Veterinary Laboratory

Medicine Interpretation and

Diagnosis, Philadelphia :

Saunders.

Muhyi YD, Zulfian, Carolia N, Tjiptaningrum A. influence the granting of extracts of themangosteen rind (garcinia mangostana 1.) ureum and creatinin levels of rats (rattus norvegicus) white male sprague dawley strains on isoniazid induction Medical
Faculty of Lampung Universitydalam

Nangaku M. Chronic hypoxia and tubulointerstitial injury: a final commonpathway to end-stage renal failure. J Am Soc Nephrol 2006;17:17-25.

Ojiako, O. A.1 dan Nwanjo, H. U. Is Vernonia amygdalina hepatotoxic or hepatoprotective? Response from biochemical and toxicity studies in rats

Okolie, U. V., Okeke, C. E., Oli, J. M., \& Ehiemere, I. O. (2008, November 4). Hypoglycemic indices of Vernonia amygdalina on postprandial blood glucose concentration of healthy humans. African

Journal of Biotechnology.

Oyugi, D., Luo, X., Lee, S., Hill, B., dan Izevbigie, B. (2012). Activity Markers of the AntiBreast Carcinoma Cell Growth Fractions of Vernonia amygdalina Extracts. NIHCenter for Environmental Health Journal. 39217.

Price, Sylvia. dan Wilson, Lorraine. 1994. Patofisiologi 2, Konsep Klinis Proses-Proses Penyakit. Penerbit Buku Kedokteran. Jakarta

Rianita Juniati, Prevalensi angka penyakit Gagal Ginjal di Indonesia Diperkirakan 400 
Ribu (Tanggal diakses: 25

Maret 2015)

Santoso Djoko, 2008. Prilaku Pasien

Penderita Gagal Ginjal Kronik

Yang Menjalani Terapi

Hemodialisa Di RSU (Tanggal

diakses: 25 Maret 2015)

Sukandar, Enday. 2006. Gagal Ginjal dan Panduan Terapi

Dialisis.Bandung : Pusat

Informasi Ilmiah Bagian Ilmu

Penyakit Dalam FK.UNPAD.

Sumarny R, Parodi D, Darmono. 2006.

Pengaruh pemberian ekstrak kering rimpang temu putih

(Curcuma zedoria. Rosc.) per

oral terhadap beberapa

parameter gangguan ginjal

pada tikus putih jantan.

Majalah Farmasi Indonesia.

17(1) : 19-24.

Supranto, J. 2000. Teknik Sampling untuk Survei dan Eksperimen. Penerbit PT Rineka Cipta, Jakarta

Wijayakusuma, H., S. Dalimartha, dan

A.S. Wirian. 1996. Tanaman Berkhasiat Obat di Indonesia. Jilid 4. Pustaka Kartini, Jakarta

Yeap, S. K., Ho, W. Y., Beh, K. B., Liang, W. S., Ky, H. Y., Abdul H. N., et al.(2010, Oktober 22). Vernonia amygdalina, an ethnoveterinary and ethnomedical used green vegetable with multiple bioactivities. Journal of Medicinal Plants Research. 